INTERNATIONAL JOURNAL OF RESEARCHES IN BIOSCIENCES, AGRICULTURE AND TECHNOLOGY (C) VISHWASHANTI MULTIPURPOSE SOCIETY (Global Peace Multipurpose Society) R. No. MH-659/13(N) www.ijrbat.in

\title{
SOME NEW REPORTS OF TREE SPECIES FROM CHANDRAPUR DISTRICT OF MAHARASHTRA, INDIA.
}

\author{
N. S. Dudhe and T. Srinivasu \\ PGTD of Botany, Rashtrasant Tukadoji Maharaj Nagpur University, Nagpur- 440033 (M.S.) \\ Email-nishigandhadudhe@gmail.com
}

\begin{abstract}
:
For the preparation of digital database of some dicot plants of Chandrapur District many periodical survey were conducted. Flora of Chandrapur and Gadchiroli district has been already studied by Moghe (1992) and Malhotra and Moorthy (1992) Flora of Taroba National Park. Botanical survey of India, Calcutta separately. Since then no survey was conducted of the area. During survey of Chandrapur district encountered 04 new rare tree species belonging to 04 families that are not reported previously from Chandrapur district. The species are Miliusato mentosaRoxb. (Annonaceae), Adansonia digitata L. (Bombacaceae), Couroupita guianensis Aubl.(Lecythidaceae) and Dendrophthoe falcate Etting. Var. coccinea (Loranthaceae). A taxonomic description along with Electronic Herbarium were prepared for each taxon.
\end{abstract}

Keywords: New reports of plant species, Electronic Herbarium, Chandrapur District

\section{INTRODUCTION:}

Maharashtra state of India has a rich treasure of Forest and Chandrapur district one of them. Chandrapur endowed with Tadoba tiger reserve forest and it is surrounded by1342 sq. $\mathrm{Km}$, moderately dense forest of 1592 sq. $\mathrm{Km}$ and open forest of 1140 sq. Km. due to sufficient forest area and open land Chandrapur District is very rich in the biodiversity and known as 'District of forest'. It lies between 18041' and 200 50' north latitude and 780 48' and 800 55' east longitude and has an area of $11417 \mathrm{sq} \mathrm{Km}$. the district is bounded on North by Bhandara District, Nagpur District and Wardha District on the east by Gadchiroli district, on the south by Adilabad and Karimnagar District of Telangana and west by Yavtmal district and comprising 15 talukas namely Chandrapur, Ballarpur, Bhadravati, Warora, Bramhapuri, Chimur, Nagbhid, Pombhurna, Sindewahi, Mul, Saoli, Gondpipari, Rajura, Korpana and Jivati respectively the average rainfall is $1276.50 \mathrm{~mm}$. The air is generally dry over the district except during the south west monsoon season when the humidity exceeds 70 per cent. The summer months are the driest when the relative humidity in the afternoon is between 20 and 25 percent
(http:/culture.maharashtra.gov.in/English/gazettee r/CHANDRAPUR).

Electronic herbarium is defined as "high resolution virtual images of plant specimen in digital format" (Srinivasu, 2005). Herbarium is the collection or depository of dried plant specimen. Herbarium serves as vital link for various disciplines of biology not only to provide information about plants from the preserved specimens but also to give insight, the changes occurred in the existing plant biodiversity with past ones from time to time.

Studies on Angiospermic dicotyledonous plants of Chandrapur district of Maharashtra with special reference to preparation of digital database and electronic herbarium of dicot plants provide comprehensive information by using software, DELTA (Descriptive Language for Taxonomy) (Dalwitz et al.2000) is a flexible and powerful method of recording taxonomic descriptions for computer processing is used for organizing a database on dicot plants. During the preparation of digital database of Dicot plants of Chandrapur district, these four plant species reported new to this region.

The flora of Chandrapur district which was initially studied by Moghe (1992) and Malhotra and 
Moorthy (1992). However, after 20 years there are many changes viz. addition and deletion of some plants in this area so it is important to know the status of these plants in nature. Afterwards many in this as the addition to the flora of Chandrapur district viz. Tiwari (1990); Patil (1991); Chavan et al., (2011);. Deshmukh et al., (2012); Shende et al., (2012); Rathor et al., (2013); Dudhe and Srinivasu (2013); Wadekar et al., (2013): Dudhe et al., (2016 ) and Dudhe et al., (2018). However recent urbanization and industrialization has affected the flora and fauna of Chandrapur and its surroundings a lot. From biodiversity and conservation point of view it is very necessary to explore existing floristic structure of Chandrapur district to update and revise the earlier data.

\section{METHOD AND MATERIAL:}

Extensive field survey was undertaken during research work in different places of Chandrapur district, 4 rare tree species of 4 different families were reported new for this area, collected from different areas including forest, villeges and outskirts habitat and details of taxonomical description entered into the computer after identification and authentification of specimen with the help of floras [Flora of Maharashtra State: DicotyledonsVol I and II (Singh et. al., 2000, 2001), Flora of Maharashtra (Almeida 1996,1998,2001and 2003 ), Flora of British India (Hooker, 1885), Flora of Chandrapur and Gadchiroli district Ph. D. thesis, Nagpur University Nagpur (Moghe, 1992) and Ethnobotanical studies of Chandrapur and Gadchiroli district Ph. D. thesis, Nagpur University Nagpur (Tiwari,1990)] the digital images are attached after processing to the respective plant description in the database.

\section{RESULT AND DISCUSSION:}

For the preparation of digital database of dicot plants of Chandrapur district, In the present study author collected four specimens belonging to families Annonaceae, Bombacaceae, Lecythidaceae and Loranthaceae from research area were reported new addition to the Chandrapur district. The specimens are enumerated below. The flowering and fruiting seasons, ecology, localities in the district of the plants also cited in the text.

\section{Family:Annonaceae}

\section{Miliusato mentosa (Roxb.) Sinclair.}

Citation: in Gard. Bull. Singapore 14: 378, 1955; Uvariato mentosa Roxb., Cor. P1. 1: 31, t.55, 1797; Cooke, Fl. Pres. Bombay 1: 16, 1901; Almeida, Fl. Maharashtra 1: 14, 1996; Singh \& Karthikeyan, Fl. Maharashtra State (Dicot) 1 : 169, 2000.

A large tree, young shoots tomentose. Leaves membranous, ovate-oblong, rounded at the base, tomentose. Flowers leaf-opposed or subterminal, pedicels 2-4 cm long; sepals minute; petals 3+3, the exterior small, longer than the sepals, linear, acute, inner ovate-oblong, larger, pubescent; stamens numerous, in several rows, shortly apiculate.; ovaries broadly ovate, ovules 4-6, in 2 rows. Fruits $5-15$ in a cluster, $2.5 \mathrm{~cm}$ long, sub-globose, succulent, purple when ripe.

Common names: Kari, Thoska, Minmara.

Place of collection: Somnath.

Status of plant in Nature: Wild.

Flowering \& fruiting period: April-June.

Uses: Fruit is edible.

Family: Bombacaceae

Adansonia digitata L.

Citation: $S p$. Pl. 1190, 1753; Master in Hook. f., Fl. Brit. Ind. 1:348, 1874; Ugemuge Fl. Nagpur Dist. 63, 1986; Almeida, Fl. Maharashtra 1: 129, 1996; Singh \&Karthikeyan, Fl. Maharashtra State (Dicot) 1: 345, 2000.

Large deciduous tree; stem much broader at the base, narrow upwards, 1000-2000 cm high, gray, shiny.Leaves deciduous, digitate, leaflets 3-9, obovate-lanceolate, long petiolate. Flowers solitary axillary, large on long pedicels; sepals 5, lobes oblong lanceolate; petals 5, white, recovered; stamen many fused at base, monoadelphous, anthers linear; ovary densely villous; style long. 
Fruit capsule, cylindrical-oblong, woody, covered with silky hairs; seeds enclosed in pulp.

Common name: Goraka chinch.

Place of collection: N.H. College Brahmapuri, Sat kholi area, Ballarpur

Status of plant in Nature: Rare for Chandrapur district.

Flowering \& fruiting period: April-June.

Uses: Fruit pulp used in dysentery. Decoction of bark is useful for malaria.

Family:Lecythidaceae

\section{CouroupitaguianensisAubl.}

Citation: Hist. Pl. Guian. 708, t. 282, 1775; Ugemuge, Fl.Nagpur Dist. 172, 1986; Almeida, Fl. Maharashtra 2: 258, 1998; Singh et al.,Fl. Maharashtra State (Dicot) 2: 23, 2001.

Tall trees. Stem 1000-1300 cm high. Leaves oblong, obovate, 10-15 cm long, 4-6 cm broad, entire, acute. Flowers cauliflorous in long racemes near the base of trunk, bracteates , bracteolate, $10 \mathrm{~cm}$, broad, 7 $\mathrm{cm}$, long, reddish outside, crimson lilac in side sepals 6, suborbicular, obtuse, thick; petal 6, obovate, glabrous shiny outside, thick, fleshy spathulateandrophore large; stamens many, filament thick, anther white; carpel 6 , stigmatic disc stellate, ovules many, placentation partite. Fruit berry, globose, reddish-brown, pulpy, with hard shell, foul smell after ripening.

Common name: Cannan ball tree.

Place of collection: Manikagad cement factory area.

Status of plant in Nature: Rare for Chandrapur district.

Flowering\& Fruiting period: October-December.

Uses: Cultivated, leaves are used in skin disease.

Family:Loranthaceae

\section{Dendrophthoe falcate Etting var.coccinea}

In Pi Saurashtra 34, 1953 \& Fl. Khandala ed. 3,234,1967; Almeida, Fl. Maharashtra 1: 265, 1996; Singh \&Karthikeyan, Fl. Maharashtra State (Dicot) 1: 838, 2000.
Branches stout, lenticellate. Leaves broadly ovate, shortly petiolate; sepal rugose outside; limb often 5notched; petal bright, scarlet; lobes short; filaments scarlet. Fruit ovoid, crowned by the calyx-limb, hard, rugose.

Place of collection: Bhadravti, Shegaon, Warora and Kalmana

Status of plant in Nature: Epiphyte.

Flowering \& Fruiting period: February- March.

\section{Conclusion}

Recent survey indicates Chandrapur district of Maharashtra state is found to be one of the important biodiversity rich areas and still some alien species regularly introduced due to modernization and urbanization, Digital database preparation is technologically a step ahead in the revision of the flora of Chandrapur district with some advancement will be updated.

\section{REFERANCE :}

Almeida, M. R. 1998-2003. Flora of Maharashtra (Vol. I- IV), IV, Orient Press, Mumbai, buildings, Bank Street, Ashford, Kent.

Chavan, V. B., Rathor, O, S..Deshmukh, U. B. and Shende, M, B, (2011) Occurence of Alysicarpusbuplerifolius (L.) var. Hybridus DC. (Fabaceae) from Chandrapur district of Maharashtra State BIOINFOLET 8 (4) : 376377

Dallwitz, M. J., Paine, T.A., \&Zurcher, C. J. (2000) DELTA program package $4.12 \mathrm{ed}$.

Dudhe, N. S. and T. Srinivasu (2013) Electronic Herberium of Chandrapur District in special and Gondpipri, Rajura and Ballarpur taluka in particular.Journal of Science Information/ special issue 6 PP 211-213.

Dudhe, N. S., T. Srinivasu and Dudhe S. S. (2016) The diversity and distribution of new species of family Fabaceae in Chandrapur District of Ballarpur taluka. Journal of Global Biosciences Vol. 5 (9), PP 4634-4637.

Dudhe, N. S., T. Srinivasu and Dudhe S. S. (2018) New Plant records for the Chandrapur District 
of Maharashtra, India.International Journal of Life Sciences, 195-197 pp.

Hooker, J. D. (1885) Flora of British India (Vol. I VIII), L. Reeve \& Co. Ltd., Lloyds Bank.

http://biodiversity.uno.edu/delta/.

Malhotra, S. K. and Moorthy, S. (1992) Flora of Taroba National Park. Botanical survey of India, Calcutta.

Moghe,R.P.(1992) Flora of Chandrapur and Gadchiroli district, Ph.D.Thesis. Nagpur University,Nagpur Nagpur University, Nagpur

Patil, B. M. (1991) Flora of Chandrapur and Gadchiroli district, Ph.D.Thesis.Nagpur University, Nagpur

Rathor, O, S., Deshmukh, U. B. and Shende, M, B, (2013). Rostellularialatispica(Gamble), Almeida : an endemic species of Acanthaceae from Chandrapur district of Maharashtra State. BIOINFOLET10 (3b): 1067-1068

Shende, M. B., Deshmukh, U. B. and Rathor, O. S., (2012) Invasive alien angiosperm of Chandrapur district of Maharashtra (India). BioNano Frontier, International Society of Science and Technology Mumbai Special issue : P. 100-103.

Singh, N. P., Lakshminarasimhan, P., Karthikeyan, S. andPrasanna, P.V. (2000) The Flora of Maharashtra State, Vol. II, BSI, Calcutta.

Singh, N.P. \&Kartikeyan, S. (2000) Flora of Maharashtra state Vol.1, BSI, Calcutta.

Srinivasu, T. (2005) Electronic Herbarium and Digital Flora of Mumbai. Proc. Of 2 nd NATWED pp.20-24.

Tiwari, V.J. (1990) .Ethnobotanical studies of Chandrapur and Gadchiroli district.Ph.D.Thesis.

Wadekar, M. B., Tondare, M. J. and Rangari M. U. (2013) Ethnomedicinal plant wealth used for the treatment of the Jaundice by the tribal communities of Chandrapur district (MS) Journal of Science Information special issue 6 PP 159-164. 
